SCIENTIFIC RESEARCH 



\title{
ACCOUNTING REFORM IN UK: HARD ROAD TO TRAVEL BUT YET POSSIBLE MOTIVATION FOR CZECH ARMED FORCES
}

\author{
Vladimír GOLIK, M.A., Ing., BA \\ Prof. M.A. Miroslav KRČ, CSc. \\ University of Defence, Brno, Czech Republic
}

\begin{abstract}
The aim of this article is to enrich discussions on possible usage of resource accounting for the purpose of defence resource management. The article discusses the issues of implementation and benefits of RAB - an accounting system which was implemented in British army few years back. Discussing this, the article follows the previous research and publication activities done by researchers from Univerzita obrany in Brno (Czech Republic) who deal with rationalization of resource management in defence.

The main attention of the article is paid to the gradual implementation of the new accounting system. The following lines shortly describe interconnection and hierarchy of individual conceptual and strategic measures, the fulfilment of which has finally led to the full implementation of resource accounting in the British defence sector. Having done this, the long-term goal was finally achieved. The article also contains brief summary of benefits which this system brings to the British army and emphasizes the importance of this accounting concept. For the purpose of this article, descriptive method is mostly used.
\end{abstract}

Keywords: RAB, resource accounting, military expenditures, effective resource allocation

\section{Need for better resource allocation}

No nation in the world can well-exist without securing such a basic, primary need, which is the feeling of safety. Neither their economies can. State security is currently becoming more and more connected with the ability to face threats 
of not only the military character, but also the non-military ones. It is important to count on growing external impacts which cannot be controlled or forecast on the national level. These impacts are the result of growing globalisation and they approve themselves in economic and informational areas. With the growing asymmetric security threats we start to understand a collision as conflict, which uses unexpected and non-traditional approaches in order to undermine power of the enemy and endanger his vulnerable positions with new technologies or other modern means. To be successful in such a conflict means to understand these asymmetric threats and be prepared to react to them accordingly.

Due to these particular reasons we need more and more resources to be able to keep our fighting power. Unexpectedness of the current conflicts lays greater demand on increased flexibility and operational standards when using the resources. Therefore, it is necessary to be constantly looking for new ways how to use these resources better and more effective.

The reform of resource management in the UK defence sector was actually a part of public sector reforms. Finding new ways towards more effective resource allocation was started with the conservative policy in the first half of eighties. After the collapse of Bipolar World experts for the defence sector started discussing intensively the question of radical improvement of defence resource management. The then stimulus for this improvement was necessity to reduce and transform defence bodies in conformity with the current security environment. Great emphasis was put on economization and new approach towards more economic solutions was stimulated using method value for money which consists in reaching $3 \%$ savings in the ministry of defence budget per year. However, it turned out that only this method would not suffice. In accordance with another method called Planning, programming and budgeting systems, the attention of reformers turned to reduction of production inefficiency, which meant more reasonable usage of the allocated resources.

A part of the defence resource reform was also change in the way accounts were kept - the then cash-based accounting system was transformed or, shall we say, replaced with $R A B$ system, the origins of which result from the business accountancy. The resource management systems were set so that they reflected responsibility, authority, competence and transparency. The idea of integrating business concept into defence management went out of the existence of notional 
analogy between private business and army (which is service provider). The implemented reforms therefore drew from the possibility of using private sector experience for the army purposes (army is the subject which creates goods in the form of defence potential). They also highlighted the necessity to evaluate the defence bodies not only based upon their ability to fight, but also from the value index point of view (defence control presumes maintaining as much economy, suitability and efficiency as possible). For these reasons the military purposes gain also the characteristics of business purposes and the commanders take role of managers, the task of whom is to run their business effectively.

The system of resource management in defence is based on three main elements which are interconnected: System of planning, programming and budgeting; budgetary structure; continuous resource management during the year.

\section{Genesis of a New Approach Towards Resource Management}

In the eighties the British government decided upon radical transformation for defence industry using a set of reforms called New Public Management. Its primary goal was to reach more rational resource usage and gradual reduction of production inefficiency (or general modernisation and reengineering of public sector run). This primary idea was based on premise that market-oriented management of public sector would lead to bigger savings in the government expenses. One of the foundation-stones of the whole concept was a change in the way accounts had been kept up to that time - a new accounting system $R A B$ (Resource Accounting and Budgeting) was decided to be implemented. This integrated system stems from business accounting, the principles of which it uses, including so called accrual principle (i.e. applying accrual basis for costs and revenues), depreciations for long-term property etc.

However, the transformation process, of the original accounting system into new uniform accounting with clearly defined inputs, was not easy at all. It took more than 10 years. Until 2001 the Ministry of defence had had to use cash-based accounting system (Talbot). Such an old way of keeping records using receipts 
and expenditures limited, to a large extent, all proceedings. Especially due to the following reasons:

- The system ignored consumption of the stock supplies and did not enable to use all sources available.

- The executed expenditure was considered to be used resource. There was not even any accrual resolution between costs and expenditures.

- Only the inputs were under consideration, not outputs. What is more, the outputs were considered to be expenditures without any subsequent identification or matching with the service.

Absence of (not only) the abovementioned elements promoted implementation of the new accounting system, which would allow for maximizing effectiveness in the defence resource allocation and minimizing costs. Comparing with the previous accounting system (which was focused on receipts and expenditures), $R A B$ enables to classify costs and trace them, considering the purposefulness. Therefore it provides better survey about the current situation in the accounting entity, and creates wide range of application of economic and transparent management while at the same time it improves managerial decision-making procedures. Thanks to the optimal financial management it is possible to strengthen and increase budgetary discipline, respect principles of efficiency, purposefulness and costs efficiency.

The Government recommendation for implementation was that the new accounting concept was laid in accordance with Generally Accepted Accounting Standards/GAAP. These accounting standards are adapted so they meet specific requirements for inspection in government and parliament. The purpose of this step was to secure wide range consistency between accounting in the public sector and experience applied in the private sector.

In the public sector, the implementation process was started on 30th November 1993. At the time it was announced in public that the intention of the Government is to implement new accounting system within the whole public sector. This intention was initiated by publishing Green paper (1994) which developed the idea of implementing new accounting reform and replacement of the previous accounting system. A year later (1995) the White paper was published, which gave recommendations to the individual Government departments to keep accounts on the accrual basis (for the period of 1998-1999 and the years to come). The 
White paper defined individual departmental procedures for application of the new accounting standards in the public sector, including obligatory terms for the gradual implementation of the individual stages, i.e. time plan for applying accounting principles into practice. The aim was fully implemented resource accounting. The resource accounting was supposed to improve management of individual departments by providing better reflection of real activity costs. Better assets management was also expected. (Office of the Comptroller and Auditor General, 1995).

The table bellow summarizes the process of implementation. It also stresses the key milestones which are connected to $R A B$.

\begin{tabular}{|l|l|}
\hline 1993 & Proposal for transition to resource accounting. \\
\hline 1994 & $\begin{array}{l}\text { Department of Exchequer published Green paper called Better Accounting for } \\
\text { Taxpayer's Money: Resource Accounting and Budgeting in Government, } \\
\text { A Consultation Paper. }\end{array}$ \\
\hline 1995 & Department of Exchequer published White paper. \\
\hline $\begin{array}{l}1998 / 99, \\
1999 / 00, \text { and } \\
2000 / 01\end{array}$ & Resource accounts: „Dry-run“ \\
\hline 1999 & Resource budgets: Dry-run test finished \\
\hline $2001 / 02$ & Resource accounting starts to be officially used. \\
\hline $2001 / 02$ and & $\begin{array}{l}\text { Transition period for resource budgets: large non-cash entries are not included } \\
\text { in Departmental Expenditure Limits (DEL) yet. }\end{array}$ \\
\hline $2002 / 03$ & $\begin{array}{l}\text { Full implementation of resource accounts. Departmental Expenditure Limits } \\
\text { contain not only cash-entries, but also non-cash entries. }\end{array}$ \\
\hline
\end{tabular}

Source: (Economic and Research Council, 2005).

Table 1. Time plan for implementation of RAB into practice - key milestones

When the new accounting system had been decided upon, there were four shadow years to come (periods from 1997-98 up to 2000-01), where accrual accounting was merely formal element and accounts were published for public only in the last period. The set of resource accounts for the period 1999-2000 and 2000-2001 was then published together with the accounts kept on cash-based system. As can be seen in the table above, since fiscal year 2003/2004 the British defence sector has been using accounts kept on resource basis; the system which had replaced original cash-based accounting concept. The time has shown that implementation of $R A B$ is considered to be a long-time process (see the table above). 
The following table summarizes the individual phases of resource accounting implementation within the public sector.

\begin{tabular}{|l|l|l|l|l|}
\hline \multirow{2}{*}{ Period } & \multicolumn{3}{|l|}{ 'Shadow years' of resource accounting } & $\begin{array}{l}\text { Implementation } \\
\text { of RAB in } \\
\text { practice }\end{array}$ \\
\hline & $\begin{array}{l}\text { Unaudied, } \\
\text { unpublished }\end{array}$ & $\begin{array}{l}\text { Audited, } \\
\text { unpublished }\end{array}$ & $\begin{array}{l}\text { Audited, } \\
\text { published }\end{array}$ \\
\hline $1993-94$ & & & & \\
\hline $1994-95$ & & & & \\
\hline $1995-96$ & & & & \\
\hline $1006-97$ & & & & \\
\hline $1997-98$ & $\mathrm{X}$ & & & \\
\hline $1998-99$ & & $\mathrm{X}$ & & \\
\hline $1999-00$ & & & $\mathrm{X}$ & \\
\hline $2001-01$ & & & $\mathrm{X}$ & \\
\hline $2001-02$ & & & & $\mathrm{X}$ \\
\hline
\end{tabular}

Source: (Heald, 2005).

Table 2. Individual phases for resource accounting implementation

The whole implementation was approved by Public Accounts Committee/PAC. It took long eleven years to finish the process of creating new, uniform system with clearly defined accounting inputs and with a possibility of annual publication of efficiency indicators. The financial management reform in the public sector is characterised by full implementation of $R A B$ system as late as in 2003/2004. All was in accordance with the original time schedule which was set in the abovementioned White paper from 1995. The then Chancellor of the Exchequer Andrew Smith proclaimed:

'This is a very significant day for Government. From now on, the Government will be using best practice in financial management... The implementation of resource accounting and budgeting puts

Britain among the world leaders in public service reform.'

(Hyndman \& Connolly)

Resource accounting is one of the elements which have helped to make resource management in defence more effective. Using information from resource accounts is basis for planning and control of public expenditures. 


\section{Benefits of $R A B$}

Implementation of $R A B$ resulted in the bigger cohesion between economic information which were demanded for managerial purposes and the information which were needed for budget allocation and decisions upon the service management. If we talk about specific benefits of accrual accounting for the defence sector, we can highlight especially:

- Providing information on purpose and sort of costs.

- Providing information on performance.

- Providing information on units.

- Calculation system set up.

- Liability within units set up.

- Standard cost control, indirect costs setting.

The system is also important to secure equivalent comparison of activities at the individual units. The implementation of the system has brought changes in the management and control. This eventually led to change of mindset. Generally $R A B$ offers better survey, assets utilization, performance measurement, improvement of financial control. This enables much better comparison of economic indicators. (Archibald, 2002).

For defence sector and its budget this change represents fundamental transition from the previous accounting concept to a totally new system. ${ }^{1}$ Although many problems occured while the system was being implemented, still $R A B$ represents a unique managerial tool without which it would not be possible to reach effective management. Thanks to it, the financial management in UK defence has become

1 It is important to mention that Great Britain was not the first country which implemented $R A B$ system. Very similar approach can be found at the Australian Department of Defence. Thanks to the managerial accounting, the financial statements depict this Department of Defence as business which is even paying outn dividends - this attributes to self-financing. The reality shows that Australian Department of Defence is financed by means, for which it provides defence service to the nation. The Department of Defence is then run (within the bounds of possibility), as private enterprise. For the application of New Public Management, which was approved by Australian government, it was demanded that the accounting systems were adapted to the new and unique operational environment because the financial statement must truly reflect the financial results. So the revenues and costs were finally clearly distinguished and costs were matched with performance. (Barton, 2004) 
a process of self-discipline and persistent control over activities, which are in accordance with the set-principles and legal regulations; process, the main functions of which are planning, monitoring, control and investing in the way the financial and budgeting stability in the sector is maintained, no matter what the other conditions are.

The process of $R A B$ implementation was executed according to the financial management cycles. First, managerial accounting was implemented, then planning and finally resource management throughout a year. Odds are that the implementation of $R A B$ was not managed without certain difficulties. Extreme pressure was put on the education area - a lot of training was provided for a few thousands employees, some positions had to be occupied by experts from the civil sector (not only temporary, but also full-time). The demands were enormous (at the beginning as much as $180 \%$ because both systems were running together and it was important to compare their differences). Naturally this resulted in higher staff turnover. Still it did not take long to see the fruits of the hard work. These are especially:

- Better use of means.

- Less property to be kept.

- Use analysis to decide if to repair or replace certain property.

- Keep stocks only in some cases or on certain level.

- Reduction of operating and indirect costs.

- Objective consideration if in specific cases outsourcing is economic solution.

- Better financial literacy.

- Availability of better information for decision-making (thus better decisionmaking).

- Identification of unusual and needless means of great extent.

- Answer for the questions - what is the result of work, how can we find out the costs, why do we need these costs.

British defence has managed to solve difficult questions which are closely connected with different economic management from the quality point of view. These are, by the way, questions which have been for some time topical even in the Czech Republic. The starter of the changes was the Ministry of Defence itself which fulfilled many important functions (coordinator, controller and auditor) for the new system. 


\section{Conclusion-why RAB?}

$R A B$ has become means of major changes in defence management and command, because new system outputs convey better information for managerial decision making and planning. These outputs are important not only for the unit commander, but also for external users. In the area of long-term assets management the resource accounting is crucial, because the performance is measured in the resources received and consumed within a certain period, depreciations for long-term property is pursued, assets and commitments are taken into account, calculations and budgets are compiled according to the resources which were really spent (not only bought), assets can be better managed (as they are recorded including all additional/supplementary costs). All this has helped to improve the resource management in the individual departments and therefore there is better tasks performance, even in case the costs for the defence must be reduced.

Now with $R A B$, the armed forces (or more precisely their commanders) know what is the total value of the means-to-be-managed. They plan and measure purposefulness and usefulness of resource spending, which enables operative management of efficiency and effectiveness in task performance.

$R A B$ is also means which is necessary for quality decision making in investments, because reflection of the current position gives a possibility to compare results in connection with past and future. Therefore this system is crucial especially in the area of planning, control and management. The presumption for successful future is understanding own past and mistakes, errors, deviations, causes and consequences which were made - and these are the sorts of information $R A B$ provides to the people responsible for defence resource management.

$R A B$ can be inspiring example for public finances and also for effective resource allocation in defence. Implementation of partial changes (economic control and decision-taking, property planning and purchase, accounting and material control) in determined transformational areas is inevitable presupposition for achieving effective resource allocation. However, it is still not sufficient. Such implementations hypothetically anticipate future events leading towards distinct improvement of economic results in a department. We cannot but agree that the expected economic results in British defence have gone the right directions. 
The main objective of the Minister of Defence in the Czech Republic cannot be implementation of managerial accounting but rather effort to give managers an unsubstitutable tool for economic control which is applicable under conditions of restricted financial resources and developing hybrid war.

\section{References}

Archibald, V. (2002). Resource Accounting: Background to Resource Accounting and Budgeting Frameset. UKDS (2nd edition).

Barton, A. D. (2004). How to Profit from Defence: A Study in the Misapplication of Business Accouting to the Public Sector in Australia. Accountibility and Management in Governments. pp. 281-304.

Black, J. (2001). Full Circle, The Cost Accounting Experiment in the British Army and the Corps of Military Accountants 1917-25, Journal of the Society for Army Historical Research (79), pp. 145-162.

Caincross, A. (1992). The British Economy since 1945. Oxford: Blackwell.

Dušek, J., \& Horák, R. (n.d.). A New Accounting and Budgeting System in British Army. Retrieved from http://rschwarz.uvadi.cz/texty/EkonACR2.pdf.

Economic and Research Council. (2005). Money Matters: Devolution and Resource Accounting and Budgeting. Retrieved from http://www.devolution.ac.uk/pdfdata/ Briefing\%2023\%20-\%20Lapsley.pdf.

Hartley, K. (n.d.). UK Defence Policy: An Economists Perspective. Retrieved from Centre for Defence Economics, University of York - England: http://web.cenet.org.cn/ upfile/53075.pdf

Heald, D. (2005). The Implementation of Resource Accounting in UK Central Government. Retrieved from Financial Accountability\& Management: http://www.davidheald.com/ publications/dra_heald.pdfs.

Hyndman, N., \& Connolly, C. The Impact of Resource Accounting and Budgeting in the Northern Ireland Public Sector. Belfast: Queen's University.

Office of the Comptroller and Auditor General. (1995). Comptroller and Auditor General Annual Report 1995. Retrieved from http://www.audgen.gov.ie/viewdoc.asp?fn=/ documents/annualreports/2005/PressRelease2005.htm.

Public Audit Forum Great Britain. (2002). The Whole Truth: Or Why Accruals Accounting Means Better Management. Retrieved from http://hdl.handle.net/10068/477232.

Talbot, P. (n.d.). Resource Accounting and Budgeting for Medical Services: The Territorial Army. Retrieved from Birmingham City University Business School: http://www.cipfa.org/-/ media/files/policy\%20and\%20guidance/the\%20journal\%20of\%20finance\%20and\%20man agement\%20in\%20public\%20services/vol\%208\%20no\%202/jour_vol8_no2_d.pdf. 